\title{
Lietuvos gyventojų rinkiminio aktyvumo teritorinė diferenciacija 2014-2016 metais
}

\section{Dovydas Vidzbelis,}

\section{Rolandas Tučas}

Vilniaus universitetas,

M. K. Čiurlionio g. 27,

03101 Vilnius

El.paštas: dovydas.vidzbelis@gf.stud.vu.lt; rolandas.tucas@gf.vu.lt
Vidzbelis D., Tučas R. Lietuvos gyventojų rinkiminio aktyvumo teritorinè diferenciacija 2014-2016 metais. Geologija. Geografija. 2018. T. 4(3). ISSN 2351-7549.

Straipsnyje nagrinejjamas Lietuvos gyventojų rinkiminis aktyvumas 2014-2016 m. regioniniu ir centras-periferija pjūviais. Remiantis užsienio ir Lietuvos autorių tyrimais, išskiriami pagrindiniai rinkimini aktyvumą lemiantys veiksniai, juos bandoma nustatyti analizuojant rinkiminio aktyvumo santykị skirtingo tipo rinkimuose. Tyrimo rezultatų pagrindu atliktas Lietuvos teritorijos elektorinis rajonavimas.

Raktažodžiai: rinkimai, rinkimų (elektorinė) geografija, rinkiminis aktyvumas, Lietuvos elektorinis rajonavimas

\section{IVADAS}

Vienas iš svarbiausių demokratinių rinkimų elementų - rinkejjai. Be jų nefunkcionuotų pagrindiniai demokratijos principai: nebūtų išrenkami atstovaujamosios valdžios pareigūnai, priimami svarbiausi valstybės sprendimai (nulemti referendumų). Rinkejuc išreikšta valia yra demokratijos pagrindas, pagal daugumos piliečių pažiūras renkami kandidatai ị svarbiausius valstybès valdymo organus.

R. J. Daltonas, analizuodamas piliečių dalyvavimą politikoje, išskyrė du pagrindinius klausimus, $\dot{i}$ kuriuos reikia atsakyti: kiek dalyvauja ir kas dalyvauja. Tačiau negalime lyginti šalių, kuriose seniai įsišaknijusi demokratija, ir pokomunistinių jaunų demokratijų. Senose demokratijose rinkejų pasirinkimas ir dalyvavimas palyginti stabilus, o jaunose - nenuspejamas. Nenuspejamam rinkejų elgesiui daugiausia ịtakos turi iki XX a. paskutinio dešimtmečio i̇sigalèjusi netradicinè politinè elgsena. Nedemokratinio valdymo laikotarpiu rinkẻjai prarado savo identitetą, rinkimų procesas tapo tik formalumas, užslopinęs pagrindines rinkejjo pareigas, sukurdamas žmogaus pasąmoneje psichologinị barjerą. Staigi politinès sistemos transformacija taip greitai nepaveikè rinkejo: politinè socializacija - ilgas procesas demokratijos raidoje (Anderson, Dalton, 2011).

Rinkiminis aktyvumas domina sociologijos, politologijos, rinkimų geografijos ir kitų mokslų atstovus. Rinkiminio aktyvumo teritorinès diferenciacijos analizė atskleidžia ne tik jo regioninius bei centras-periferija pobūdžio skirtumus, bet ir rinkeju aktyvumo skirtingo tipo rinkimuose santykị, kurio variacijas galima bandyti aiškinti susiejant su rinkejų demografiniais, socialiniais, politiniais, ekonominiais ir kt. teritoriškai diferencijuotais rodikliais.

Politologinio pobūdžio rinkiminiam aktyvumui skirtu darbu yra nemažai. 1998 m. pasirodè pirmoji politologinè kolektyvinè monografija Seimo rinkimai' 96: trečiasis atmetimas, skirta konkretiems rinkimams, kurioje net du skyriai skirti rinkiminio aktyvumo analizei (Krupavičius, 1998; Žèruolis, 1998), bei vienas (1992 ir 1996 m.) Seimo rinkimų rezultatų pagrindu išskirtiems politiniams regionams aptarti (Labulytè, 1998). Vèliau pasirodè keletas piliečių politiniam dalyvavimui skirtų teorinių darbų, kuriuose detaliai aptariamos gyventojų politinị aktyvumą lemiančios priežastys (Jasiulevičienè, 1999; Riekašius, 2004). XXI a. Lietuvos elektorato politines preferencijas, rinkejjų archetipus, rinkiminio aktyvumo priežastingumą 
nuosekliai tyrinejja politologų grupè: A. Ramonaite, M. Jastramskis, R. Žiliukaitè ir kt. (Ramonaitè, 2006; Žiliukaite, 2014).

Pirmieji rinkimų geografijai priskirtini darbai Lietuvoje paskelbti tik atkūrus nepriklausomybę, buvo remtasi pirmųjų demokratinių rinkimų duomenimis (Kavaliauskas, Daugirdas, 1993). Tačiau juose, kaip ir visuose vèlyvesniuose darbuose rinkimų geografijos tematika, rinkiminiam aktyvumui demesio skirta nedaug. Išsamiau Lietuvos gyventojų rinkiminis aktyvumas buvo aptartas V. Petrulio daktaro disertacijoje, tačiau taip pat tik vienu - esamos valdžios vertinimo - aspektu (Petrulis, 2009).

Apie rinkiminį aktyvumą yra studentų darbų, tačiau jų rezultatai mokslinèje spaudoje nebuvo publikuoti. $2011 \mathrm{~m}$. Vilniaus universiteto Geografijos ir kraštotvarkos katedroje apgintas Eglès Ivanauskytès bakalauro darbas Rinkiminio aktyvumo dinamika 1992-2011 m. teritoriniu aspektu Lietuvoje (Ivanauskyte, 2011). Tačiau tai daugiau apžvalginio pobūdžio darbas - jame gana išsamiai aptarti rinkejjų aktyvumo skirtingo tipo rinkimuose regioniniai skirtumai, tačiau tam įtakos turejusios priežastys nebuvo analizuotos arba jos pateiktos daugiau kaip prielaidos. $2017 \mathrm{~m}$. buvo parengtas VU TSPMI studentès Amandos Kvedaraitès bakalauro darbas Vietoves įtaka Lietuvos rinkejy aktyvumui (Kvedaraitè, 2017). Šis darbas svarbus metodologine prasme, taip pat jo autore analizuoja, kokią įtaką rinkimų apylinkès kompaktiškumas turi rinkiminiam aktyvumui. Rengiant ši darbą buvo susidurta su metodologinio pobūdžio problema - jo autorei keltų hipotezių pagrindimui nepavyko gauti pakankamo teritorinio detalumo duomenų, teko apsiriboti tik Vyriausiosios rinkimų komisijos tinklapyje viešinamais duomenimis, tad kelti tyrimo uždaviniai buvo igyvendinti tik iš dalies.

Apibendrinant tikslinga pažymèti, kad kol kas rinkiminis aktyvumas Lietuvoje tyrinètas mažai, ypač trūksta geografinio pobūdžio darbų, kurie konstruktyviai papildytų politologinio tipo rinkiminio aktyvumo tyrimus ir galbūt padètu nustatyti geografines rinkimini aktyvumą lemiančias priežastis bei prisidètų optimizuojant elektorines teritorijas (rinkimų apylinkes ir apygardas). Šio tyrimo tikslas - nustatyti Lietuvos gyventojų rinkiminio aktyvumo priežastis teritoriniu aspektu.

\section{TYRIMO METODOLOGIJA}

Šiam tyrimui panaudoti 2014 m. Lietuvos Respublikos Prezidento rinkimų mažoritarinès sistemos dalies, 2015 m. Lietuvos Respublikos savivaldybių tarybų ir Lietuvos Respublikos Seimo rinkimų proporcinès sistemos dalies rinkiminių apylinkių lygmens duomenys. Visi duomenys gauti iš Lietuvos Respublikos Vyriausiosios rinkimų komisijos (VRK) internetinio tinklapio (http:// www.vrk.lt/). Analizei pasirinkti vèliausiai vykę rinkimai. Be to, rinkiminio aktyvumo skirtingo tipo rinkimuose palyginimas geografiniu požiūriu suformuoja galimybę aiškiau suvokti rinkiminio aktyvumo skirtumus lemiančias priežastis regioniniu, o ypač miestas-kaimas požiūriu.

Šioje publikacijoje gyventojų aktyvumas rinkimuose nagrinejamas dviem aspektais: aptariant rinkiminio aktyvumo teritorinę diferenciaciją ir atliekant rinkiminio aktyvumo skirtingo tipo rinkimuose palyginamąją analizę. Rinkiminio aktyvumo teritorinei diferenciacijai analizuoti pasirinktas trijų skirtingo tipo rinkimų aktyvumo rezultatų vidurkinimas ir gautų rezultatų atvaizdavimas kartoschemoje. Rinkiminio aktyvumo skirtingo tipo rinkimuose palyginamajai analizei sudarytos dvi kartoschemos, kuriose pateikiamas $2015 \mathrm{~m}$. LR savivaldybių tarybų rinkimų - 2016 m. LR Seimo rinkimų ir 2016 m. LR Seimo rinkimų - 2014 m. LR Prezidento rinkimų rezultatų santykio teritorinis pasiskirstymas. Nustatant rinkiminio aktyvumo santyki tarp savivaldybių tarybų rinkimų ir centrinès šalies valdžios - Seimo rinkimų rezultatų, galima hipotetiškai santykinai (lyginant su kitais regionais ir pan.) išmatuoti rinkejjų pasitikejjimą vietos valdžia, bendruomeniškumo efektą. Rinkiminio aktyvumo Seimo ir Prezidento rinkimuose palyginimas su tam tikromis išlygomis (Pietryčių Lietuva ir pan.) rodo rinkejjų santykinai didesnę paramą vieno asmens (Prezidentas) ar kolektyvinei (Seimas) valstybès centrinès valdžios institucijai, iš ko galima spręsti, ar rinkejjai teikia prioritetą nuomonių pliuralizmui ir partinei demokratijai, ar konkrečiame regione santykinai didesnè rinkèjų dalis labiau simpatizuoja vieno asmens valdžiai (prielaida, kad regiono rinkejjams artimesnis autoritarinio valdymo siekis). Tačiau jokiu būdu šių prielaidų negalima sureikšminti, nes didžia dalimi tai priklauso nuo regiono. Pavyzdžiui, 
Pietryčių Lietuvoje itin populiari regioninè partija - Lenkų rinkimų akcija, tad rinkejų aktyvumas šiame regione Seimo ir savivaldos rinkimuose yra didesnis nei Prezidento rinkimuose, bet tai nereiškia, kad šis regionas iš viso Lietuvos konteksto išsiskiria didesne parama partinei demokratijai. Tai priklauso ir nuo tokių gana subjektyvių rinkiminiam aktyvumui veiksnių kaip konkurencijos tarp politinių jègų intensyvumas, politiko asmenybės bruožai (kandidato gimtosios vietos ir kt., teritorinis kontekstas), pagaliau ir vietos valdžios pozicija (ypač mažesnèse savivaldybėse).

Be to, tyrimas atliktas tik 2014-2015 m. Lietuvoje vykdytų rinkimų pagrindu. Kad būtų galima aiškiau identifikuoti rinkiminio aktyvumo tendencijas bei jų priežastis, reiktų analizuoti gerokai platesnị laikotarpí, apimantị daugiau pasikartojančių rinkimų. Tai bus atliekama vèliau tęsiant ši tyrimą.

Kartoschemų rengimui, duomenų analizei naudoti specifiniai šiam tyrimui sukurti teritoriniai vienetai, kurie suformuoti savivaldybių viduje $\mathfrak{i}$ vientisus teritorinius vienetus jungiant (panaudojus ArcGIS for Desktop programos Dissolve funkciją) bendrus bruožus turinčias rinkimų apylinkes. Toki pasirinkimą lèmé šio tyrimo tikslas - rinkiminio aktyvumo pažinimas ne tik regioniniu, bet ir centras-periferija pjūviu. Lietuvoje šiuo metu (2018 m.) yra 1995 teritorinès rinkimų apylinkès, tad jų nejungiant $\mathfrak{i}$ stambesnius teritorinius vienetus kartoschemose vaizduojami rezultatai būtu sunkiai skaitomi. Rinkimų apylinkès i stambesnius teritorinius vienetus sujungtos ne bet kaip, o pagal jose dominuojančiu gyvenamųjų vietovių tipą. Rinkimų apylinkių grupavimą pagal ši kriterijų atliko vienas iš šio darbo bendraautorių Rolandas Tučas, šis grupavimas jau buvo naudotas VU TSPMI studentès Amandos Kvedaraitès bakalauro darbe (Kvedaraité, 2017). Pagal rinkimų apylinkèje dominuojančių gyvenviečių tipą, rinkimų apylinkès buvo suskirstytos i šešias grupes: didžiųjų miestų; vidutinio dydžio miestų; priemiesčių; mažųjų miestų; miestelių ir didesnių gyvenviečių; kaimiškųjų vietovių. Šiame tyrime visos konkrečioje savivaldybeje esančios vieno ar kito tipo rinkimų apylinkès buvo sujungtos (ArcGIS Desktop programos Dissolve funkcija) i̇ vientisas teritorijas darant prielaidą, kad jų rinkejjai pasižymi panašiais socialiniais ir demografiniais bruožais, t. y. sudarytų teritorijų ribos suderintos su savivaldybių ribomis (jų nekerta) ir i viena teritorini vieneta jungia tik to paties tipo rinkimų apylinkes. Būtent toks sprendimas yra racionaliausias randant optimalų santykị tarp duomenų bei rezultatų detalumo ir kokybiško tiriamo reiškinio pateikimo kartoschemose (jeigu būtų pateikiama savivaldybèmis, sunkiau identifikuoti centro-periferijos skirtumus; pateikiant rinkimų apylinkėmis - dèl jų smulkumo (miestuose) rezultatu pateikimas kartoschemose būtų nekokybiškas). Taigi, iš 1995 m. rinkimų apylinkių buvo sudaryti 239 šiame tyrime naudoti teritoriniai vienetai.

Tikslinga trumpai apibūdinti R. Tučo išskirtus rinkimų apylinkių tipus:

1. Didžiųjų miestų tipui priskirtos 377 Vilniaus, Kauno, Klaipèdos, Šiaulių, Panevèžio ir Alytaus miestų rinkimų apylinkès. Nors didmiesčio sąvoką galima aiškinti įvairiai, tačiau šiuo atveju vienas iš svarbesnių kriterijų, kad didmiestis (nors kartais turintis ir šiek tiek mažiau nei 100 tūkst. gyventojų) turi būti kaip savarankiška savivaldybè. Be to, ne visos didmiesčiu savivaldybèse esančios rinkimų apylinkès priskirtos didmiesčių kategorijai. Kai kurios (pvz., Balsių, Salininkų ir kt.) priskirtos priemiesčiams.

2. Vidutinių miestų tipui priskirtos 263 rinkimų apylinkès. Tai savivaldybių centrai bei kai kurie kiti didesni (per 5 tūkst. gyventojų turintys) miestai: Kuršènai, Kybartai, Lentvaris, Nemenčinè.

3. Priemiesčių tipui priskirta 281 rinkimų apylinkè. Tai suburbanizacijos proceso paveiktos greta didžiųjų ir vidutinių miestų esančios rinkimų apylinkès. Jų plotas didesnis už miestiškų, turi daug rinkejjų, dauguma gyventojų yra santykinai didesnes pajamas gaunantys, dažniausiai mieste dirbantys asmenys.

4. Mažųjų miestų apylinkių tipui priskirta 51 rinkimų apylinkè. Tai miesto statusą turinčių gyvenviečių (gyventojų skaičius dažniausiai varijuoja tarp 1 500-2 000) rinkimų apylinkès. Dauguma mažųjų miestų yra atskiros seniūnijos, tačiau jie nèra savivaldybių centrai. Kai kurios apylinkès jungia ir gretimas kaimiškas vietoves, tačiau jose vis tiek dominuoja miesto gyventojai. Mažuosiuose miestuose beveik visada yra gimnazija, prekybos centrai, įmonès, dauguma jų gyventojų verčiasi ne žemès ūkio veikla. Mažiausia gyventojų turinčių miestų (Panemunès, Troškūnų, 
Smalininkų ir kt.) rinkimų apylinkès priskirtos miestelių ir didesnių gyvenviečių kategorijai.

5. Miestelių ir didesnių gyvenviečių rinkimų apylinkių kategorijai priskirtos 322 rinkimų apylinkès. Šiose teritorijose paprastai būna mokyklos (dažniausiai - pagrindinès, rečiau - gimnazijos), kultūros ìstaigos, dažniausiai jos būna ir seniūnijų centrai. Iš esmès visada šios kategorijos rinkimų apylinkès apjungia ne vien miestelių, didesnių gyvenviečių, bet ir greta jų esančių kaimų gyventojus, tačiau šio tipo apylinkèse aiškiai dominuoja miestelių ir kt. didesnių gyvenviečių rinkejjai. Gyventojų užimtumas įvairus - dominuoja žemès ūkyje dirbantys asmenys, tačiau yra nemažai dirbančių aptarnavimo sektoriuje, išsilavinusių inteligentijos atstovų ir kt.

6. Kaimiškųjų vietovių rinkimų apylinkių kategorijai priskirtos 699 rinkimų apylinkès. Tai dažniausiai mažai (mažiau nei 500) rinkejjų turinčios, santykinai nemažą plotą užimančios rinkimų apylinkès, kur gyventojų dauguma yra ar buvo susiję su žemés ūkiu. Paprastai šio tipo rinkimų apylinkès yra atokiau nuo miestų, aiškiai dominuojančios didesnès gyvenvietès jose nèra (nèra ir ugdymo, kultūros ịstaigų), balsavimo vietos įrengiamas maždaug 100-200 gyventoju turinčiuose kaimuose.

\section{LIETUVOS GYVENTOJŲ RINKIMINI AKTYVUMĄ LEMIANTYS VEIKSNIAI}

Norint nagrinèti rinkimini aktyvumą svarbu išskirti veiksnius, kurie turi įtakos rinkejjų sprendimui dalyvauti ar nedalyvauti rinkimuose. Ju yra daug, be to, kiekvienam rinkejjui gali turèti ittakos vis kiti ir saviti veiksniai. Todèl tikslinga išskirti rinkiminiam aktyvumui įtakos turinčių veiksnių grupes, kurios apimtų pagrindinius svarbiausius rodiklius. Kadangi rinkimini aktyvumą nagrinèjantys Lietuvos mokslininkai nèra sudarę tokios klasifikacijos, todèl remtasi keliais užsienio autorių darbais (Bulhlmann, 2006; Anderson, Dalton, 2011), jų ižzvalgas susiejant su Lietuvos specifika. Kadangi šiame tyrime nebuvo atliekamos rinkèjų kiekybinès apklausos, tam, kad būtų aiškiau išskirti ir sugrupuoti Lietuvos rinkejjų aktyvumą lemiantys veiksniai, pasiremta politologès Rūtos Žiliukaitès atlikta Lietuvos gyventojų rinkimini aktyvumą lemiančių veiksnių analize, kuri paremta visuotinemis apklausomis vykdant pro- jektą manobalsas.lt (Žiliukaitė, 2014). Remiantis Lietuvos rinkèjų aktyvumą lemiančių veiksnių analize ir užsienio šalių metodologine patirtimi, buvo išskirtos aštuonios veiksnių grupès: socialinio ir ekonominio statuso, socialinių tinklų, politinių (pilietinių) igūdžių, paramos politinèms partijoms, politinès sistemos funkcionalumo, geopolitinès įtakos, geografinių, gamtinių sąlygų ittakos ir kt. (žr. 1 pav.). Socialinio ir ekonominio statuso, politinių (pilietinių) igūdžių, paramos politinèms partijoms veiksnių grupès šiame tyrime išskirtos kaip vidinių veiksnių grupès. Vidinių veiksnių grupèms priskirti veiksniai tiesiogiai priklauso nuo rinkejo: jo socialinio statuso, išsilavinimo, patirties, psichologijos ir kitu individualių savybių. Analogiškas variantas - išorinių veiksnių grupès, kurioms priskirti rinkiminiam aktyvumui itakos turintys veiksniai yra nepriklausomi nuo rinkejo. Tai gali būti šalies vidaus politinis kontekstas, žiniasklaidos įtaka, geopolitinès ir net gamtinès priežastys. Taip pat atskirai išskirtos socialinių tinklų ir kitų veiksnių grupès. Šias grupes veikia tiek vidinès, tiek ir išorinès priežastys, todèl schemoje jos pateiktos atskirai.

Socialinio ir ekonominio statuso veiksniu grupei priskirti amžiaus, lyties, tautybès, išsilavinimo, užsièmimo (profesinis) ir pajamų veiksniai. Tyrimai rodo (Žiliukaité, 2014), kad kuo vyresnis rinkejjas, tuo didesnè tikimybé, jog jis ateis ị rinkimus. Iš apibendrintų 1996-2012 m. duomenų matyti, kad dalyvavimas rinkimuose pagal amžiaus grupes pasiskirsto taip: 18-24 metų, tikètina, kad ateis balsuoti $50 \%$ rinkejjų; 25-30 metų - $61 \%$; 31-40 metu - $64 \%$; 41-50 metu - $73 \%$; 51-60 metu - $75 \%$; 61-70 metų - $80 \%$; 71 metų ir vyresni - 75 \% (Žiliukaitè, 2014). Vyriausių asmenų grupès aktyvumas sumažeja, tačiau tai lemia daugiau fiziologiniai veiksniai - ne visų senyvo amžiaus asmenų sveikata leidžia dalyvauti rinkimuose. Tyrimai rodo, kad rinkiminis aktyvumas šiek tiek priklauso ir nuo asmens lyties. Lietuvoje aktyvesnès moterys, nors yra pasitaikę rinkimų, kai aktyvesni buvo vyrai (pvz., 2012 m. LR Seimo rinkimuose). Tautybe taip pat gana svarbus veiksnys, kadangi Lietuvoje yra politinių partijų, kurios atstovauja tautinėms mažumoms. Tokio pobūdžio partijos per rinkimus stipriai mobilizuoja savo rinkèją (pvz., itin aukštas Pietryčių Lietuvos gyventojų rinkiminis aktyvumas). Išsilavinimas 


\begin{tabular}{|c|c|c|c|c|c|c|}
\hline \multicolumn{3}{|c|}{$\begin{array}{l}\text { Vidinių veiksniu grupès } \\
\text { Internal factors groups }\end{array}$} & \multirow[b]{2}{*}{\begin{tabular}{|} 
Socialiniụ tinklụ \\
Social \\
networking
\end{tabular}} & \multicolumn{3}{|c|}{$\begin{array}{l}\text { Išorinių veiksnių grupès } \\
\text { External factors groups }\end{array}$} \\
\hline $\begin{array}{c}\text { Socialinio ir } \\
\text { ekonominio } \\
\text { statuso } \\
\text { Social and } \\
\text { economic status }\end{array}$ & $\begin{array}{c}\text { Politiniụ } \\
\text { (pilietinių) } \\
\text { igūdžiụ } \\
\text { Political (civil) } \\
\text { skills }\end{array}$ & $\begin{array}{l}\text { Paramos } \\
\text { politinèms } \\
\text { partijoms } \\
\text { Support for } \\
\text { political parties }\end{array}$ & & $\begin{array}{l}\text { Politinès } \\
\text { sistemos } \\
\text { funkcionalumo } \\
\text { Political system } \\
\text { functionality }\end{array}$ & $\begin{array}{l}\text { Geopolitinès } \\
\text { itakos } \\
\text { Geopolitical } \\
\text { influence }\end{array}$ & $\begin{array}{c}\text { Geografiniụ, } \\
\text { gamtinių } \\
\text { sąlygụ } \\
\text { Geographic, } \\
\text { natural } \\
\text { conditions }\end{array}$ \\
\hline $\begin{array}{l}\text { Amžius } \\
\text { Age }\end{array}$ & $\begin{array}{l}\text { Domejjimasis } \\
\text { politika } \\
\text { Interest in } \\
\text { politics }\end{array}$ & $\begin{array}{l}\text { Pasitikejimas } \\
\text { partijomis, } \\
\text { politikais } \\
\text { Confidence in } \\
\text { parties, } \\
\text { politicians }\end{array}$ & $\begin{array}{l}\text { Socialine sąveika } \\
\text { Social } \\
\text { interaction }\end{array}$ & $\begin{array}{l}\text { Rinkimų } \\
\text { sistemos } \\
\text { funkcionalumas } \\
\text { Election system } \\
\text { functionality }\end{array}$ & $\begin{array}{l}\text { Užsienio } \\
\text { valstybių } \\
\text { propaganda } \\
\text { Foreign } \\
\text { propaganda }\end{array}$ & $\begin{array}{l}\text { Atstumas iki } \\
\text { apylinkès } \\
\text { Distance to } \\
\text { constituency }\end{array}$ \\
\hline $\begin{array}{l}\text { Išsilavinimas } \\
\text { Education }\end{array}$ & $\begin{array}{l}\text { Dalyvavimas } \\
\text { ankstesniuose } \\
\text { rinkimuose } \\
\text { Participation in } \\
\text { previous } \\
\text { elections }\end{array}$ & $\begin{array}{c}\text { Partinis } \\
\text { tapatumas } \\
\text { Party identity }\end{array}$ & $\begin{array}{c}\text { Priklausymas } \\
\text { bendruomenems, } \\
\text { organizacijoms } \\
\text { Belonging to } \\
\text { communities, } \\
\text { organizations }\end{array}$ & $\begin{array}{l}\text { Politinių partijų } \\
\text { ir politiku } \\
\text { ivaizdžio kaita } \\
\text { The image of } \\
\text { political parties } \\
\text { and politicians }\end{array}$ & $\begin{array}{c}\text { Užsienio } \\
\text { valstybiu įtaka } \\
\text { politikams } \\
\text { The influence of } \\
\text { foreign countries } \\
\text { on politicians }\end{array}$ & $\begin{array}{l}\text { Oro salygos } \\
\text { Weather } \\
\text { conditions }\end{array}$ \\
\hline $\begin{array}{l}\text { Užsièmimas } \\
\text { (profesinis) } \\
\text { Profession }\end{array}$ & $\begin{array}{c}\text { Politinio } \\
\text { išprusimo lygis } \\
\text { Political } \\
\text { awareness level }\end{array}$ & $\begin{array}{c}\text { Grèsmès } \\
\text { prielaida } \\
\text { Premise of threat }\end{array}$ & $\begin{array}{l}\text { Gyvenamoji } \\
\text { vieta } \\
\text { Residence }\end{array}$ & $\begin{array}{l}\text { Valdančiosios } \\
\text { daugumos ir } \\
\text { opozicijos } \\
\text { veiklos } \\
\text { efektyvumas }\end{array}$ & & $\begin{array}{l}\text { Metų laikas } \\
\text { Season }\end{array}$ \\
\hline \multirow[t]{3}{*}{$\begin{array}{l}\text { Pajamos } \\
\text { Earnings }\end{array}$} & \multirow[t]{3}{*}{$\begin{array}{l}\text { Pilietinis } \\
\text { aktyvumas } \\
\text { Civil activity }\end{array}$} & \multirow{3}{*}{\multicolumn{2}{|c|}{$\begin{array}{l}\text { Kiti veiksniai } \\
\text { Other factors }\end{array}$}} & $\begin{array}{l}\text { Effectiveness of } \\
\text { the governing } \\
\text { majority and the } \\
\text { opposition }\end{array}$ & & \\
\hline & & & & $\begin{array}{l}\text { Rinkiminė } \\
\text { agitacija } \\
\text { Election } \\
\text { agitation }\end{array}$ & & \\
\hline & & & & & & \\
\hline
\end{tabular}

1 pav. Lietuvos rinkiminį aktyvumą lemiantys veiksniai

Fig. 1. Factors determining Lithuanian election activity

visame pasaulyje yra vienas pagrindinių veiksnių, lemiančių rinkimini aktyvumą. Ši veiksni R. Žiliukaitė išskiria iš penkių pagrindinių veiksnių, lemiančių Lietuvos rinkejjų dalyvavimą rinkimuose. Remiantis po $2012 \mathrm{~m}$. Seimo rinkimų vykdytos rinkejjų apklausos duomenimis, rinkiminis aktyvumas pagal gyventojų išsilavinimą pasiskirstè taip: pagrindinis ir žemesnis išsilavinimas - $53 \%$; vidurinis - $57 \%$; specialusis vidurinis ar aukštesnysis - $73 \%$; aukštasis neuniversitetinis - $70 \%$; aukštasis universitetinis - $80 \%$ ) (Žiliukaite, 2014). Galima konstatuoti, kad kuo aukštesnị išsilavinimą yra igijęs asmuo, tuo didesne tikimybè, kad jis dalyvaus rinkimuose. Pagal užimtumą apklausos duomenys pasiskirstė taip: aukštos kvalifikacijos specialistų ar vadovų rinkimuose dalyvauja $84 \%$; valstybès tarnautoju - $77 \%$; prekybos ir paslaugu sektoriaus darbuotojų - $67 \%$; kvalifikuotų, pusiau ar nekvalifikuotuc darbuotojų - $59 \%$; niekada nedirbusių mokamo darbo - 39 \% (Žiliukaité, 2014). Kaip matome, kuo aukštesnis asmens socialinis statusas, tuo didesnè tikimybe, kad jis dalyvaus rinkimuose. Pajamų veiksnys, skirtingai nei prieš tai aptartieji, jau ne visada turi tiesinę priklausomybę. Tikètinas rinkejjų aktyvumas pagal pajamas: iki 800 Lt gaunantys asmenys - $61 \%$, nuo $801 \mathrm{iki}$ $1500 \mathrm{Lt}-64 \%$, nuo 1501 iki $2000 \mathrm{Lt}-74 \%$, nuo 2001 iki $2800 \mathrm{Lt}-78 \%$, daugiau nei $2801 \mathrm{Lt}$ - 68 \% (Žiliukaitè, 2014). Apklausų 
rezultatai atskleidè, kad didejant asmens pajamoms dideja ir tikimybè, jog jis balsuos rinkimuose. Iš bendro konteksto išsiskiria daugiausia pajamų gaunančių asmenų grupè. Galima daryti prielaidą, kad dauguma didesnes pajamas gaunančių žmonių užsiima verslu ir turi mažiau laisvo laiko, nei dirbantys terminuotą darbo dieną.

Politiniu (pilietiniu) igūdžiu veiksniu grupei priskirtini šie veiksniai: asmens doméjimąsis politika, dalyvavimas ankstesniuose rinkimuose, politinio išprusimo lygis, pilietinis aktyvumas. Kuo asmuo labiau domisi politika, tuo didesnè tikimybe, kad jis atvyks ì rinkimus. Politinemis partijomis, kandidatais ir apskritai politika besidomintis asmuo didina tikimybę, kad ras sau artimą kandidatą ar partiją ir dèl to ateis balsuoti. Taip pat politika besidomintys asmenys paprastai geriau supranta rinkimų prasmę ir naudą stabiliai demokratijai. Politologai išskiria ir dalyvavimo ankstesniuose rinkimuose veiksni, kaip vieną svarbiausių, lemiančių Lietuvos gyventojų rinkimini aktyvumą. Dalyvavimas ankstesniuose rinkimuose - tai iprotis balsuoti, vadinasi, kuo daugiau rinkimuose balsavęs asmuo, tuo didesnè tikimybè (tris kartus didesnè nei asmens, kuris neturi balsavimo patirties ar balsavo labai mažai kartų), jog jis balsuos ir ateityje. Pilietinis aktyvumas - labai svarbus veiksnys ne tik rinkimų procese, bet ir kitose politinio dalyvavimo akcijose (mitinguose, viešuose visuomenès svarstymuose ir kt.). Pilietiški asmenys jaučia pareigą ateiti ì rinkimus net ir tada, kai nèra apsisprendę dèl savo politinių preferencijų vienai ar kitai politinei jegai. Neretai tokie asmenys ateina balsuoti, nors neišreiškia jokios paramos ir sugadina rinkimų biuleteni.

Paramos politinems partijoms veiksniu grupei priskiriami pasitikejjimo partijomis ar kandidatais, partinio tapatumo, grèsmès prielaidos veiksniai. Politologè Rūta Žiliukaitė teigia, kad paklausus asmenų, kodèl jie neatejo balsuoti, penki iš dešimties atsakys, kad nepasitiki partijomis ar politikais. Galima teigti, kad šis veiksnys yra vienas pagrindinių, lemiančių Lietuvos rinkèjų pasirinkimą nebalsuoti. Tai patvirtina po $2012 \mathrm{~m}$. Seimo rinkimų atliktas tyrimas (Žiliukaité, 2014). Partinis tapatumas yra vienas tinkamiausių rodiklių nustatant asmens aktyvumą rinkimuose. To paties tyrimo rezultatai rodo, kad 9 iš 10 asmenų, prijaučiantys kuriai nors Lietuvos politiniai par- tijai, dalyvavo ir žada dalyvauti ateityje vyksiančiuose rinkimuose. Tačiau rinkejjus gali skatinti eiti i rinkimus ne tik partinis tapatumas, bet ir baimé ar nenoras, kad i valdžią patektų jų ypač nemègstama partija, kurią jie sieja su tam tikromis grèsmèmis.

Socialiniu tinklu veiksniu grupei priskirti socialinès sąveikos ir priklausymo bendruomenèms ar organizacijoms veiksniai. Socialinė aplinka veikia individų politinį aktyvumą, socialinè sąveika atsiskleidžia per du rodiklius: 1) „artimo žmogaus“ ir 2) tèvų parama politinèms partijoms. Kaip rodo apklausos duomenys (Žiliukaitè, 2014), jeigu rinkejjo "artimų žmonių“ tinkle yra asmenų, kurie remia kurią nors politinę partiją ar kandidatą, yra didesne tikimybè, kad jis balsuos rinkimuose. Priešingu atveju arba jei rinkejjas yra izoliuotas nuo socialinès ir politinès komunikacijos (t. y. negali nurodyti nei vieno asmens, su kuriuo galètų aptarti jam svarbius klausimus), yra mažiau tiketina, kad jis balsuos rinkimuose. Ta pačia tendencija išsiskiria ir tèvų paramos politinèms partijoms nuostatos: jei bent vienas iš tèvų remia kurią nors politinę jègą ar kandidatą, išlieka didesnè tikimybè, kad ir tas asmuo dalyvaus rinkimuose (tèvų parama politinèms partijoms veikia tik jaunesnius rinkejus). Priklausymas bendruomenèms ar organizacijoms taip pat reikšmingas ir susijęs su jau aptarta sąveika su „artimu žmogumi“, tačiau yra ir daugybe kitu veiksnių. Pirmiausia bendruomenèms ar organizacijoms priklausantys asmenys yra lengviau mobilizuojami. Pavyzdžiui, Romos katalikų bažnyčios svarbiausios pamaldos vyksta sekmadieniais, kurie Lietuvoje sutampa su balsavimo rinkimuose diena, todèl tokius asmenis lengva mobilizuoti. Bendruomeniškumo jausmo vedami bendruomenès nariai neretai santykinai aktyviau eina ị rinkimus. Iš apklausų galima matyti, kad šiais bruožais pasižymi dauguma didesnèms bendruomenėms ar organizacijoms priklausančių asmenų (Žiliukaitè, 2014). Gyvenamosios vietos veiksnys taip pat yra svarbus: miestelių ir kompaktiškų gyvenviečių gyventojai pasižymi didesniu bendruomeniškumu, o vienkiemių ir miestų - individualumu, todèl miestelių gyventojai, tikètina, balsuos aktyviau nei vienkiemių ar miestu gyventojai.

Politines sistemos funkcionalumo veiksniu grupei priskirti rinkimų sistemos funkcionalumo, politinių partijų ir politikų ịvaizdžio kaitos, 
valdančiosios daugumos ir opozicijos veiklos efektyvumo, politinès agitacijos veiksniai. Rinkimų sistemos funkcionalumas rinkiminiam aktyvumui daugiausia pasireiškia per rinkimų teritorijų ir rinkimų tvarkos pokyčius. Pakitę rinkiminių apygardų, apylinkių ribos, balsavimo vietos adresas ar rinkimų sistemos dedamosios gali atgrasyti rinkejją nuo balsavimo rinkimuose. Politinių partijų ir politikų įvaizdžio kaita pasireiškia per politinius skandalus, korupcines bylas, apkaltas. Šie reiškiniai mažina rinkejų pasitikejjimą partine sistema ir demokratijos veikimu, todèl neigiamai veikia rinkimini aktyvumą. Rinkiminiam aktyvumui svarbu ir valdančiosios daugumos bei opozicijos veiklos efektyvumas - jei valdančiosios daugumos ir opozicijos veikla nèra aktyvi per tam tikrą kadenciją, tikètina, kad artejjančiuose rinkimuose rinkiminis aktyvumas sumažès, ir atvirkščiai - pasitikejjimą kelianti efektyviai dirbanti valdančioji dauguma arba opozicija dažniausiai skatina rinkejjus aktyviau dalyvauti rinkimuose. Rinkiminé agitacija - labai svarbus abejojanti rinkejją tiesiogiai motyvuojantis veiksnys. Paprastai ji padeda lengviau apsispręsti ir dažniausiai didina rinkimini aktyvumą. Taip pat rinkiminè agitacija prisideda ir prie elektorato mobilizavimo rinkimu procesui.

Geopolitinès ịtakos veiksniu grupei priskirti veiksniai: užsienio valstybių propaganda per žiniasklaidos priemones ir užsienio valstybiu tiesiogine itaka politikams. Šiai veiksnių grupei būdingas bendras bruožas - jų šaltinis yra užsienis. Daugiausia tam ịtakos turi ne itin Lietuvai draugiškos kaimynès Rusija ir Baltarusija. Kadangi Lietuvoje yra su šiomis šalimis susijusios tautinès mažumos, todèl atsiranda nebloga kultūrinè terpe veikti tam tikroms politizuotoms užsienio šalių žiniasklaidos priemonèms. Neretai per šias žiniasklaidos priemones yra transliuojama propaganda, kontraversiška nuomonè dèl vienų ar kitų rinkimų, referendumų. Agituojama neiti arba atvirkščiai - aktyviai dalyvauti rinkimuose ir referendumuose, priklausomai nuo konkrečiai užsienio valstybei parankių klausimų (referendume) ar partijų bei politikų (rinkimuose). Neretai kandidatai, kuriems daroma itaka iš užsienio valstybių, ịsivelia ị skandalus, apkaltas (šių veiksnių i taka rinkimams jau aptarta ankstesnejje veiksniu grupeje) - tai taip pat turi itakos rinkiminiam aktyvumui.
Geografiniu, gamtiniu salygu veiksniu grupei priskirti oro sąlygų ir metų laikų, atstumo iki balsavimo vietos veiksniai. Nors Lietuvoje ir nèra fiksuojama pasaulinio lygmens stichinių nelaimių ar kitų nepalankių gamtinių sąlygų, tačiau šie veiksniai daro nemažą įtaką rinkiminiam aktyvumui. Oro sąlygos labai priklauso nuo metų laikų - panašios oro sąlygos gali nevienodai veikti rinkimini aktyvumą skirtingu metų laiku. Tikètina, kad pavasarí, vasarą ir ankstyvą rudeni mažiausias rinkiminis aktyvumas yra tada, kai džiugina geri orai (saulèta, giedra, šilta ir t. t.), kadangi rinkimai ir referendumai vyksta sekmadieniais, o savaitgaliais rinkejjai turi kitų planų (poilsis gamtoje, kelionès, darbai soduose ir kt.). Rudenį ir žiemą, atvirkščiai, kuo geresni orai, tuo didesnè tikimybè, kad susirinks daugiau rinkejjų. Gamtinių sąlygų veiksniai didžiausią įtaką daro dvejojantiems asmenims, nes apsisprendžiama spontaniškai. Tam țtakos turi ir kartų skirtumai (vyresni žmones dažniau pavasarị ir rudenị savaitgaliais laiką leidžia soduose, o jaunimas dažniausiai būna išvykęs vasarą ir t. t.). Gamtinių sąlygu veiksnys yra sudètingiausiai nuspejjamas iš visų aptartų. Atstumas iki balsavimo vietos yra vienas iš pagrindinių veiksnių, kuriuos išskiria racionalumo teorija. Tiketina, kad asmenys, kuriems toli nuvykti iki balsavimo vietos, balsuos santykinai rečiau nei tie, kuriems ji yra greta. Tačiau, analizuojant atstumo iki balsavimo vietos ittaką rinkiminiams aktyvumui, riekia nepamiršti ir aplinkybių svarbos. Pavyzdžiui, jei apygardoje kandidatuoja du stiprūs panašaus pajègumo kandidatai, jie visais įmanomais būdais stengsis paskatinti kuo daugiau rinkèjų dalyvauti rinkimuose ir savo balsą atiduoti už juos (gali būti organizuojamas transportas rinkejjams atvežti ir t. t.). Be to, nereikia pamiršti, kad apylinkių komisijos rengia išankstinius balsavimus - aplanko atokiau nuo balsavimo vietos gyvenančius pagyvenusius, ligotus asmenis.

Kitu veiksniu grupei priskirti palankumo sovietiniams laikams, dalyvavimo Sąjūdžio veikloje ir kt. savitesni veiksniai. Tai daugiau būdinga vyresnès kartos asmenims. Mažesnè tikimybè, kad rinkimuose balsuos asmenys, kurie palankiau vertina sovietinius laikus, nes jiems demokratija neretai nèra prioritetas, taip pat tam itakos turi ir nusivylimas esama politine tvarka. Tiketina, kad asmenys, dalyvavę Sąjūdžio veikloje, aktyviau 
balsuos, nes jie padejo pamatus demokratijos vystymuisi šalyje, supranta jos svarbą ir ịvertina skirtumus, palyginti su nedemokratiniu valdymu. Rinkiminiam aktyvumui įtakos gali tureti ir kitos priežastys (patirtis emigracijoje, psichologiniai veiksniai, ligos ir kt.), kurios visus būtų sudètinga ivardyti ir aptarti.

\section{RINKIMINIO AKTYVUMO SANTYKIS SKIRTINGO TIPO RINKIMUOSE}

Nagrinejjant rinkiminio aktyvumo veiksnius reikètų pabrèžti, kad jų santykinè svarba priklauso nuo rinkimų tipo. Nevienodo rinkiminio aktyvumo skirtingo tipo rinkimuose priežastys bei santykiné skirtingų veiksnių svarba gali būti nustatoma ne tik vykdant rinkejjų apklausas (kas šio tyrimo atveju nebuvo atliekama), bet ir analizuojant rinkiminio aktyvumo skirtingo tipo rinkimuose santyki. Pavyzdžiui, rinkiminio aktyvumo santykis dviejų skirtingo teritorinio lygmens kolektyvinių valdžios institucijų - savivaldybių tarybų bei Seimo rinkimuose parodo rinkejų bendruomeniškumą, artumo vietinio lygmens valdžiai jausmą, vietinès valdžios efektyvumo lygi ir rinkejų pasitikèjimą ja. Seimo ir Prezidento rinkimų aktyvumo santykis iš dalies parodo rinkejų palankumą demokratiniam ar autokratiniam valdymui. Rinkiminio aktyvumo santykis skirtingo tipo rinkimuose bene tiksliausiai parodo, kuriai valdžios institucijai daugiau palankumo jaučia rinkejjas (Petrulis, 2009; Tučas, 2016). Tai neatsiejamai susiję su valdymo efektyvumu ir rinkèjų pasitikejjimu konkrečia visuotinių rinkimų būdu renkama valdžios institucija. Be to, ankstesni tyrimai atskleidè, kad rinkiminis aktyvumas labai dažnai priklauso ir nuo savivaldybės dydžio - mažesnèse savivaldybėse rinkiminis aktyvumas paprastai būna didesnis (ypač savivaldos rinkimuose) nei didžiosiose savivaldybèse (Tučas, 2016). Tai sietina su mažesnèms savivaldybėms būdingais tampresniais bendruomeniniais ryšiais, glaudesne savivaldos institucijų ir savivaldybès gyventojų sąveika.

Savivaldybiu tarybu ir Seimo rinkimu skirtumas (žr. 2 pav.). 2015 m. savivaldybių tarybų rinkimuose santykinai didesniu rinkiminiu aktyvumu (palyginti su $2016 \mathrm{~m}$. Seimo rinkimais) išsiskyrè Pietų Lietuva, pietinès Žemaitijos dalies bei Rytų ir Šiaurès Rytų Lietuvos pasienio savi- valdybès. Pietinèje Lietuvos dalyje didžiausiu santykiniu rinkiminiu aktyvumu savivaldos rinkimuose pasižymèjo Lazdijų r. (išskyrus miestelių ir didesnių gyvenviečių rinkimų apylinkes), Trakų r., Alytaus r. (išskyrus didesnių gyvenviečių ir priemiesčio rinkimų apylinkes), Šalčininkų r., Kalvarijų, Birštono savivaldybès. Didesnis rinkèjų aktyvumas savivaldos rinkimuose (palyginti su 2016 m. Seimo rinkimais) buvo ir Druskininku, Varėnos r., Elektrėnų, Širvintų r., Kazlų Rūdos r. sav., kuriose yra nemažai aukšto santykinio aktyvumo apylinkių. Rytinèje dalyje savivaldybių tarybų rinkimuose aukštu santykiniu aktyvumu išsiskyrè Švenčionių r. ir Visagino sav., aukštu rinkiminiu aktyvumo pasižymèjo ir dauguma Zarasų r. sav. rinkimų apylinkių. Idomu tai, kad Vilniaus r. sav. santykinai didesniu rinkejų aktyvumu savivaldos rinkimuose išsiskyrè toliau nuo Vilniaus $\mathrm{m}$. esančios periferinès kaimiškosios šios savivaldybės rinkimų apylinkès, kuriose daugumą gyventojų sudaro lenkų tautybès mažesnes pajamas gaunantys asmenys, o suburbanizacijos procesuc stipriai paveiktose Vilniaus metropolinio regiono priemiestinèse apylinkèse rinkejjai aktyvesni buvo $2016 \mathrm{~m}$. Seimo rinkimuose. Vakarinèje Lietuvos dalyje santykinai didžiausiu rinkiminiu aktyvumu savivaldos rinkimuose pasižymèjo Pagègių ir Šilalès sav., o ne tokiu dideliu skirtumu - Neringos, Šilutės r., Tauragės r., Raseinių r., kaimiškosios Kelmès r. sav. rinkimų apylinkès. Santykinai didesnis rinkiminis aktyvumas savivaldos rinkimuose buvo būdingas ir Biržų r., Kupiškio r., Palangos $\mathrm{m}$. savivaldybėse. Pasitvirtina jau anksčiau minètas ir ankstesniuose tyrimuose (Tučas, 2016) pastebètas dèsningumas, kad mažose Lietuvos savivaldybèse (Neringos, Birštono, Pagėgių, Druskininkų, Kalvarijų, Kazlų Rūdos, Elektrènų, Visagino, Palangos m., Kupiškio r., Širvintų r.) rinkiminis aktyvumas savivaldos rinkimuose yra santykinai didesnis nei Seimo rinkimuose.

Santykinai mažiausias rinkiminis aktyvumas $2015 \mathrm{~m}$. savivaldos rinkimuose (palyginti su 2016 m. Seimo rinkimais) buvo Lietuvos didmiesčių (išskyrus Alytų) metropoliniuose regionuose, o ypač didmiesčius juosiančių „žiedinių“ savivaldybių priemiestinèse teritorijose. Net Pietryčiu Lietuvoje iš bendro Pietų ir Rytų Lietuvos regioninio konteksto „iškrenta“ Vilniaus m. ir greta Vilniaus esančios priemiestinès teritorijos, taip 


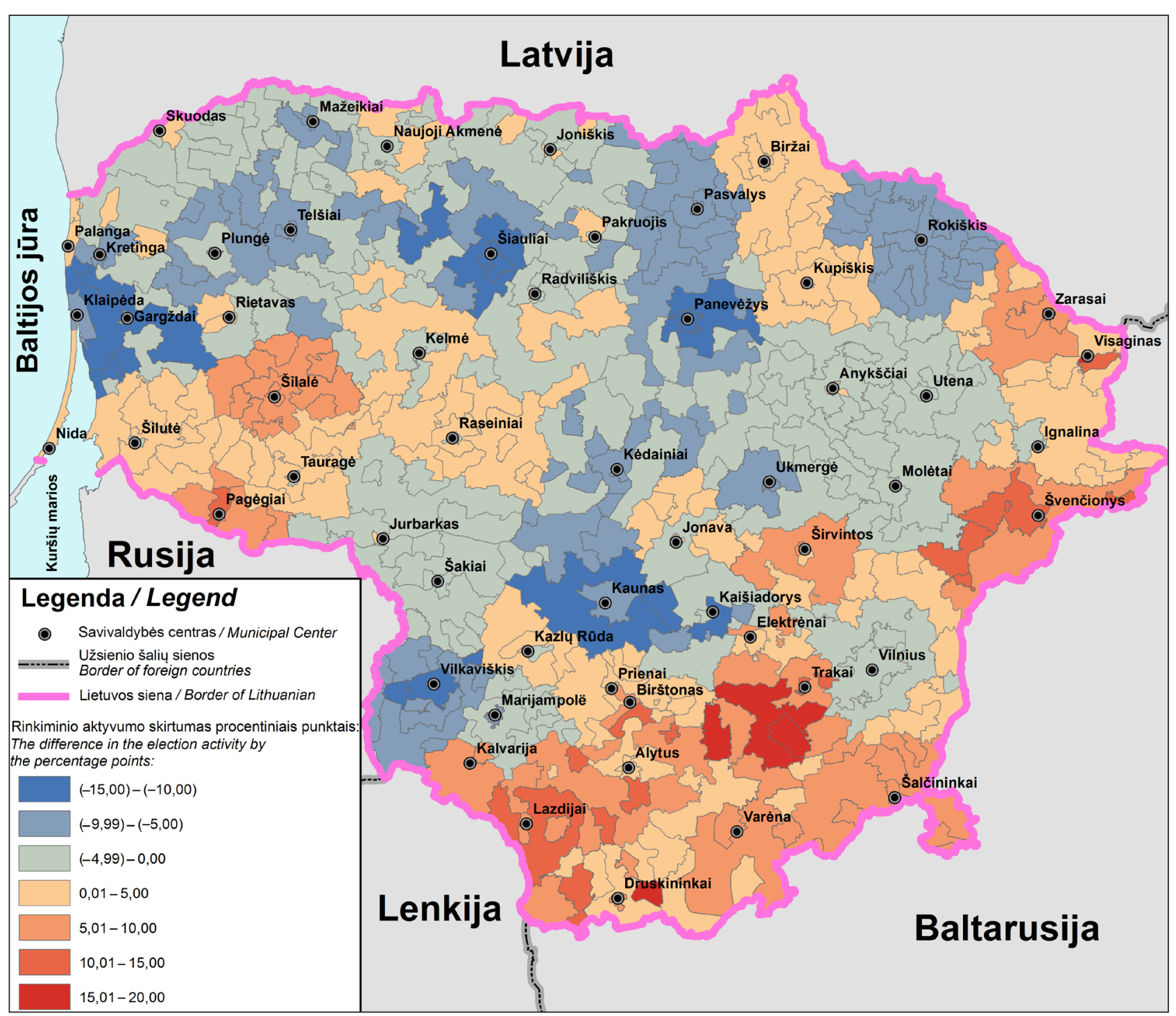

2 pav. 2015 m. savivaldybių tarybų rinkimų ir 2016 m. Seimo rinkimų rinkejjų aktyvumo skirtumai (atimant iš savivaldybių tarybų rinkiminio aktyvumo rodiklio Seimo rinkiminį aktyvumo rodiklį)

Fig. 2. Differences in activity of municipal councils election in 2015 and parliamentary election in 2016 (by subtracting parliamentary election activity from municipal councils election activity)

Pietų ir Rytų Lietuvos santykinai didesnio rinkèjų aktyvumo savivaldos rinkimuose regioną tarsi padalija $\mathfrak{i}$ dvi dalis (jei ne Vilniaus metropolinio regiono teritorinis efektas, Pietų ir Rytų Lietuvos regionas būtų vientisas). Gana aiški regionine, o ypač teritorine priklausomybe, remiantis centrasperiferija pjūviu. Vilniaus metropolinis regionas, nors ir iš bendro Rytų Lietuvos konteksto išsiskiria santykinai didesniu rinkejų aktyvumu Seimo rinkimuose, tačiau rinkiminio aktyvumo atotrūkis tarp Seimo ir savivaldos rinkimų dar nèra toks didelis kaip Kauno, Klaipèdos, Šiaulių ir Panevèžio metropoliniuose regionuose. Ypač jis ryškus (Seimo rinkimai) ne tiek pačiuose nurodytuose didmiesčiuose, kiek jų priemiestinèse zonose. Tai tik patvirtina požiūrị, kad i miesto savivaldybę nepatenkančių priemiesčių gyventojams nèra itin aktuali jų „kaimiškųjų“ savivaldybių politinè sudètis. Priemiesčiai daugumai jų tai tik gyvenamoji, laisvalaikio praleidimo erdvè. Tuo tarpu dažnam priemiesčių gyventojui aktualiau gretimo didmiesčio valdymo kokybè, nes darbiniais ir kt. ryšiais jis pirmiausia susijęs su didmiesčiu. $\mathrm{Na}$, o centrinès valdžios - Seimo rinkimai neabejotinai šiems, išsilavinusiems, aukštesnes pajamas gaunantiems Lietuvos piliečiams, yra svarbūs. Kalbant apie kaimiškąsias Šiaurès, Šiaurès Vakarų, Vidurio Lietuvos savivaldybes, kuriose Seimo 
rinkimai buvo populiaresni nei savivaldos, pirmiausia reiktų pabrěžti, kad jos pasižymi stipriu partijų dominavimu, tačiau vietos lygmenyje neišskiria asmenybėmis. Be to, tai dažniausiai tradicinių partijų (TS-LKD, LSDP, LRLS) santykinai didesnès įtakos regionai. Pavyzdžiui, Pasvalio r., Anykščių r., Utenos r., Molètų r., Skuodo r. visuose rinkimuose gana populiari buvo TS-LKD; Vilkaviškio r., Rokiškio r., Kaišiadorių r., Marijampolès, iš dalies ir Šakių r. - LSDP; Plungès r. - LRLS.

Santykinai didesniam rinkiminiam aktyvumui savivaldos rinkimuose, palyginti su Seimo rinkimais, galimai įtakos turi ir socialiné atskirtis bei gyventojų etninè sudètis. Pietryčių Lietuvoje, taip pat rytinio Lietuvos pakraščio savivaldybėse, didelę dali gyventojų sudaro ne lietuvių tautybès asmenys, kurie gana aktyviai balsuoja už savo regionines partijas (Pietryčių Lietuvoje - už Lenkų rinkimų akciją-Krikščioniškų šeimų sąjungą). Šių politinių jègų įtaka savivaldos lygmenyje gerokai didesnè nei šalies centrinès valdžios (Seimo). Ši priežastis motyvuoja rinkejją aktyviau dalyvauti savivaldos rinkimuose. Kai kuriose kitose Rytų ir Pietų Lietuvos bei Pietų Žemaitijos savivaldybėse, kuriose rinkejjai savivaldos rinkimuose dalyvavo aktyviau nei Seimo rinkimuose, itakos galejo turèti panašios priežastys. Pavyzdžiui, Švenčionių r. sav. gana ittakinga kitur Lietuvoje mažai populiari politinè partija - Lietuvos laisvès sąjunga, Varènos r. sav. - Lietuvos centro partija, Pagėgių, Šilalès r., Šilutès r., Zarasų r. savivaldybėse - partija „Tvarka ir teisingumas“. Taip pat minètų regionų savivaldybėse nemažą gyventojų dali sudaro darbo neturintys ir vyresnio amžiaus asmenys, kurie dažnokai būna nusivylę centrinès šalies valdžios vykdoma socialine politika. Taip pat galima daryti prielaidą, kad šiose savivaldybèse stipriai veikia pasitikejimo partijomis ir politikais bei rinkejų politinio tapatumo veiksniai, savivaldybès (ypač mažosios) pasižymi stipriu partijų ir jų vietinių lyderių dominavimu. Tuo tarpų didžiuosiuose Lietuvos miestuose rinkejjas labiau išprusęs, gerokai silpniau veikia lokalių socialinių tinklų veiksniai, todèl jie santykinai aktyviau dalyvauja ne savivaldos, o Seimo rinkimuose.

Seimo ir Prezidento rinkimu skirtumas (žr. 3 pav.). $2014 \mathrm{~m}$. Prezidento rinkimuose buvo pats mažiausias rinkiminis aktyvumas šio tipo rin- kimuose nuo pat nepriklausomybès atgavimo, o 2016 m. Seimo rinkimu aktyvumas išliko vidutinis. Šios priežastys turèjo įtakos ir tyrimo rezultatams - kokie nors aiškesni rinkiminio aktyvumo skirtumai neišryškejjo. Santykinai didesnis rinkiminis aktyvumas Seimo rinkimuose fiksuotas Pietų ir Rytų Žemaitijoje bei Pietų ir Centrinèje Lietuvoje. O santykinai didesnis rinkejų aktyvumas Prezidento rinkimuose - Šiaurès Rytų ir Pietryčiu Lietuvoje bei šiaurinèje Žemaitijos dalyje. Galimai didesnị rinkejjų aktyvumą Seimo rinkimuose Pietų ir Rytų Žemaitijoje bei Pietų ir Centrinèje Lietuvoje (išskyrus Kauną) lèmé tai, kad šiuose regionuose ịtakingesnių partijų politinès preferencijos yra apylygès, vadinasi, tarp partijų vyko didelè konkurencija. Galima daryti prielaidą, kad kandidatu rinkimine kompanija buvo intensyvi ir taip pritraukè daugiau rinkejjų í Seimo rinkimus. Tuo tarpu rinkėju aktyvumą balsuojant Prezidento rinkimuose lemia asmenybès. Tai pagrindinè priežastis, kodèl didžiausias skirtumas tarp Prezidento ir Seimo rinkimų (Prezidento rinkimų naudai) fiksuotas Pietryčių Lietuvoje - Šalčininkų r., Vilniaus m. ir r. savivaldybėse. Visiškai aišku, kodèl jis toks santykinai aukštas buvo Šalčininkų r., o iš dalies ir Vilniaus r. sav. - čia gyvenantys lenkų tautybès rinkejjai itin aktyviai balsavo už savo kandidatą Valdemarą Tomoševkị. Tačiau kodèl atotrūkis tarp Prezidento ir Seimo rinkimų gana aukštas liko ir Vilniaus $\mathrm{m}$. bei šio miesto priemiestinèse teritorijose, nèra aišku. Tikètina, kad iš dalies tai lèmè V. Tomoševskio kandidatavimas, gal didesnè kandidatų konkurencija nei kitur Lietuvoje. Tačiau tai tik prielaidos, nepaaiškinančios didesnio rinkejų aktyvumo Prezidento rinkimuose. Panašiai kaip ir regioninis aspektas - kodèl vienuose Lietuvos regionuose rinkejjai buvo aktyvesni Seimo, o kituose Prezidento rinkimuose - taip pat nèra aišku. Tiesa, gal šių skirtumų nederètų sureikšminti, nes atotrūkis santykinai yra nedidelis, gerokai mažesnis nei Pietryčių Lietuvoje. Dar sudètingiau atsakyti ị klausimą, kodèl Lietuvos didmiesčiuose - Vilniuje, Kaune, Klaipèdoje, Šiauliuose, Panevėžyje bei nemenkoje dalyje kitų miestų rinkimų apylinkių rinkejjai buvo aktyvesni ne Seimo, o Prezidento rinkimuose (ypač išsiskyrè Vilnius ir Klaipèda). Gal tai nusivylimas prieš $2016 \mathrm{~m}$. Seimo rinkimus i politinès korupcijos skandalą patekusiu Lietuvos Respublikos liberalu sąjūdžiu. Juk ši partija iki tol buvo gana populiari 


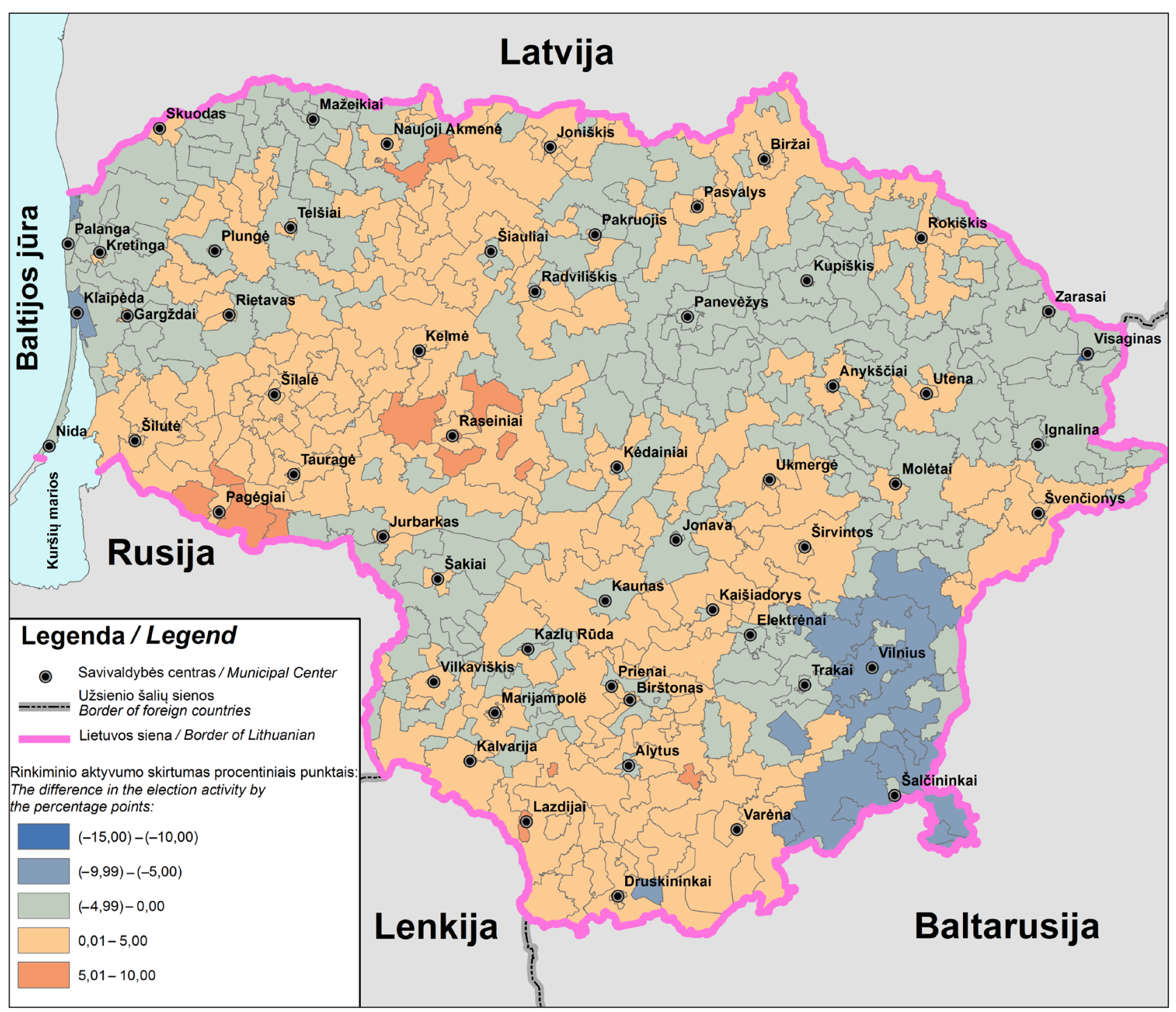

3 pav. 2016 m. Seimo rinkimų ir 2014 m. Prezidento rinkimų rinkèjų aktyvumo skirtumai (atimant iš Seimo rinkiminio aktyvumo rodiklio Prezidento rinkimų aktyvumo rodikli)

Fig. 3. Differences in activity of parliamentary election in 2016 and presidential election in 2014 (by subtracting presidential election activity from parliamentary election activity)

didžiuosiuose Lietuvos miestuose, ypač Klaipèdoje ir Vilniuje. Galima daryti prielaidą, kad nemenka dalis buvusių LRLS rinkèjų tiesiog nedalyvavo rinkimuose. Taip pat nereiktų pamiršti ir minèto fakto, kad $2014 \mathrm{~m}$. Prezidento rinkimai pasižymejjo mažesniu rinkèjų aktyvumu nei ankstesni šio tipo rinkimai. Prieš $2014 \mathrm{~m}$. Prezidento rinkimus niekam didesnių abejonių nekilo, kad juose antrai kadencijai bus išrinkta Dalia Grybauskaitè. Tad gal ši priežastis paskatino tų regionų gyventojus, kuriuose D. Grybauskaitès kandidatūra buvo mažiau populiari (išskyrus Pietryčių Lietuvą), tiesiog neatvykti i rinkimus. Tuo tarpu tarp Lietuvos didmiesčių rinkèjų D. Grybauskai- tè gana populiari, kas taip pat galèjo turèti ịtakos santykinai didesniam jų gyventojų rinkiminiam aktyvumui. 2014 m. Prezidento ir 2016 m. Seimo (I turų) rinkiminio aktyvumo palyginimas tiesiog prieštarauja politologijoje nusistovejusiam požiūriui, kad miestų rinkèjai dèl aukštesnio jų politinio išprusimo, liberalesnių pažiūrų yra aktyvesni kolektyvinès (Seimo), o ne vieno asmens (Prezidento) institucijos rinkimuose (Petrulis, 2009; Tučas, 2016). Gal tai išimtis - tik šių dviejų rinkimų rinkejų elgsenos palyginimo rezultatas. Kokios iš tiesų yra ilgalaikès tendencijos, $\mathfrak{i}$ tai bus siekiama atsakyti ateityje tęsiant ši rinkiminio aktyvumo tyrimą. 


\section{RINKIMINIO AKTYVUMO RAJONAVIMAS}

Rinkiminio aktyvumo regionų išskyrimui pasitelkti trijų skirtingo tipo rinkimų $(2014 \mathrm{~m}$. Prezidento, $2015 \mathrm{~m}$. savivaldybių tarybų ir $2016 \mathrm{~m}$. Seimo rinkimų) rinkiminio aktyvumo vidurkio duomenys. Pagal aktyvumo vidurkio rezultatus buvo išskirti trys regionai, kurie smulkiau dalinami i parajonius (žr. 4 pav.).

I aukšto rinkiminio aktyvumo regionas. Šis regionas apima pietrytinę Lietuvos dalị, kuri išsiskiria aukštu rinkiminio aktyvumo vidurkiu. Aukštam rodikliui daugiausia įtakos turi didesnis aktyvumas savivaldybių tarybų ir Prezidento rin- kimuose. Šis regionas dar dalijamas it 5 parajonius:

I. a. parajonis išsiskiria aukščiausiu rinkiminiu aktyvumu. I ji patenka visos Šalčininkų r. sav. rinkimų apylinkès ir Vilniaus r. kaimiškosios, miestelių ir didesnių gyvenviečių apylinkès. Kaimiškose Šalčininkų r. ir Vilniaus r. sav. apylinkèse vidutinis rinkimis aktyvumas viršija $60 \%$. Kitose apylinkèse variuoja nuo 55 iki $60 \%$, išskyrus Šalčininkų m. priemiestines apylinkes, kuriose rinkiminis aktyvumas mažesnis net už bendrą Lietuvos rinkiminio aktyvumo vidurkị.

I. b. parajonis apima Lazdijų r., Druskininkų, Varėnos r., Alytaus m. ir r., Birštono sav. rinkimų

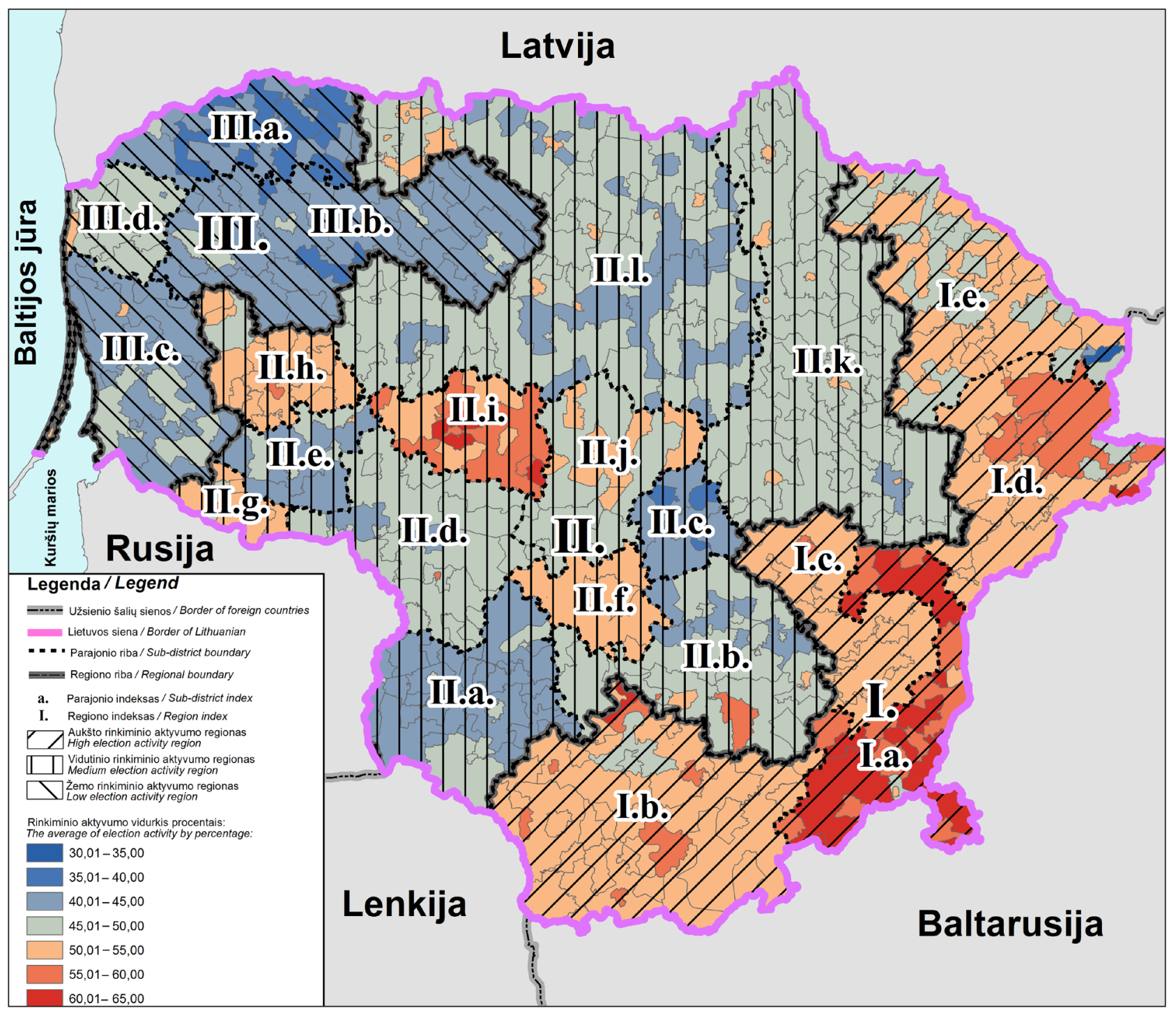

4 pav. Lietuvos rinkiminio aktyvumo regionai pagal 2014 m. Prezidento, $2015 \mathrm{~m}$. savivaldybių tarybų ir $2016 \mathrm{~m}$. Seimo rinkimų aktyvumo duomenis

Fig. 4. Regions of Lithuanian election activity according to 2014 presidential, 2015 municipal councils, and 2016 parliamentary elections activity data 
apylinkes. Didžiausiu aktyvumu (viršija 55 \%) išsiskiria Birštono sav. vidutinio miesto ir priemiesčio, Alytaus r. ir Varénos r. sav. mažųjų miestų, Lazdijų r. ir Druskininkų sav. vidutinių miestų rinkimų apylinkès. Mažesniu aktyvumu šiame parajonyje išsiskiria Alytaus m. ir jo priemiesčių rinkimų apylinkès. Galima teigti, kad kuo didesnis urbanizacijos lygis (išskyrus Alytaus m. ir jo priemiesčius), tuo šiame parajonyje didesnis rinkiminis aktyvumas.

I. c. parajonis pasižymi tik nežymiai didesniu rinkiminiu aktyvumu, palyginti su šalies vidurkiu. Parajonis apima Širvintų r., Vilniaus m. ir priemiestines Vilniaus r. sav. rinkimų apylinkes. Santykinai didesniu rinkiminiu aktyvumu parajonyje išsiskiria tik Širvintų r. sav. vidutinio miesto ir priemiesčio rinkimų apylinkès (viršija $55 \%)$. I ši parajoni patenka tik Vilniaus r. sav. priemiestinès rinkimų apylinkès. Jose rinkiminis aktyvumas mažesnis, palyginti su I. a. parajonio apylinkèmis, nes jos patena $\mathfrak{i}$ Vilniaus $\mathrm{m}$. suburbanizacijos zoną: jų gyventojai neretai dirba Vilniaus mieste ir savo sociodemografiniais bruožais yra artimesni didemisčio, o ne kaimiškųjų vietovių gyventojams.

I. d. parajonis apima Švenčionių r., Ignalinos r. ir dalị Utenos r. sav. rinkimų apylinkių. Didžiausiu rinkiminiu aktyvumu išsiskiria Švenčionių r. sav. miestelių bei didesnių gyvenviečių, Ignalinos r. sav. priemiesčio ir kaimiškosios rinkimų apylinkès. Ignalinos r. sav. išsiskiria gan netolygiai teritorijoje pasiskirsčiusiu rinkiminiu aktyvumu.

I. e. parajonis išsiskiria tiek aukštesniu, tiek ir žemu rinkiminiu aktyvumu bei netolygiu jo teritoriniu pasiskirstymu. I š ši parajoni patenka dalis Utenos r., Zarasų r., Rokiškio r. ir Visagino sav. rinkimų apylinkès. Žemiausiu rinkiminiu aktyvumu pasižymi Visagino vidutinio miesto ir priemiesčio rinkimų apylinkès, didesniu - Utenos r. ir Zarasų r. sav. apylinkès. Žemesnis aktyvumas būdingas tik šių savivaldybių priemiestinèms apylinkèms.

II vidutinio rinkiminio aktyvumo regionas. Šis regionas daugiausia apima Vidurio Lietuvą, taip pat pietinę Žemaitijos dalị ir išsiskiria netolygiu rinkiminio aktyvumo vidurkio pasiskirstymu teritorijoje. Dèl šios priežasties regione išskirta net 12 parajonių:

II. a. parajonis apima Kalvarijos, Marijampolès, Kazlų Rūdos ir Vilkaviškio r. savivaldybes.
Parajonis pasižymi mažesniu rinkiminiu aktyvumu. Santykinai aukštesnis rinkiminis aktyvumas būdingas Kalvarijos savivaldybès apylinkèms, visoms vidutinio miesto apylinkèms bei Kazlų Rūdos sav. priemiesčio apylinkèms.

II. b. parajonis išsiskiria gana ženkliu rinkiminio aktyvumo pasiskirstymo teritorijoje netolygumu. Parajonis apima Prienų r., dalị Trakų r., Kaišiadorių r. ir Elektrènų savivaldybes. Santykinai didesniu rinkiminiu aktyvumu nei šalies vidurkis išsiskiria Trakų r. sav. vidutinio miesto, Trakų r. ir Prienų r. sav. miestelių ir didesnių gyvenviečių rinkimų apylinkès, Prienų r. sav. mažu miestų rinkimų apylinkès. Santykinai mažesniu rinkiminiu aktyvumu išsiskiria Kaišiadorių r. sav. priemiesčių, miestelių ir didesnių gyvenviečių bei Elektrènų sav. priemiesčių rinkimų apylinkès.

II. c. parajonis apima Jonavos r. savivaldybę. Šis parajonis pasižymi žemu rinkiminiu aktyvumu. Santykinai didesnis rinkiminis aktyvumas būdingas vidutinių miestų apylinkèms, žemiausias - miestelių ir didesnių gyvenviečių rinkimų apylinkèms.

II. d. parajonis apima Šakių r. ir Jurbarko r. savivaldybes. Jis pasižymi mažesniu rinkiminiu aktyvumu. Santykinai mažiausiu rinkiminiu aktyvumu išsiskiria Šakių r. sav. mažų miestų ir Jurbarko r. sav. priemiesčių rinkimų apylinkès, didžiausiu (per 55 \%) - Šakių r. sav. vidutinių miestų apylinkès.

II. e. parajonis apima Tauragès r. savivaldybę. Didesniu nei šalies vidurkis rinkiminiu aktyvumu pasižymi tik Tauragès r. sav. mažų miestų rinkimų apylinkès, o mažesniu - priemiesčių, miestelių ir didesnių gyvenviečių apylinkès.

II. f. parajonis apima Kauno m., dali Kauno r. ir Prienų r. sav. rinkimų apylinkes. Rinkejų aktyvumas visame parajonyje tolygus, nedaug didesnis už šalies vidurkị. Apima didžiųjų miestų, priemiesčių, miestelių ir didesnių gyvenviečių rinkimų apylinkes. Tai dar kartą išryškina dèsningumą, kad aukštesnis rinkiminis aktyvumas tiesiogiai priklauso nuo rinkèjų išsilavinimo lygio bei politinių ir pilietinių igūdžių.

II. g. parajonis apima Pagègių savivaldybę. Didžiausiu rinkiminiu aktyvumu pasižymi Pagègių sav. vidutinių miestų rinkimų apylinkès, mažiausiu - priemiesčių. Parajoniui būdingas bendras aukštas rinkiminis aktyvumas rodo didelę paramos politinèms partijoms veiksnių ittaką. 
II. h. parajonis apima Šilalès r. sav. ir dalį Rietavo savivaldybès. Santykinai mažiausiu rinkiminiu aktyvumu parajonyje išsiskiria Rietavo kaimiškosios rinkimų apylinkès, didžiausiu - Šilalès vidutinio miesto apylinkès. Parajonio aukštą rinkimini aktyvumą lemia tie patys veiksniai kaip ir II. g. parajonyje.

II. i. parajonis apima Raseinių r. savivaldybę. Didžiausiu rinkiminiu aktyvumu pasižymi priemiesčių rinkimų apylinkès, mažesniu - miestelių ir didesnių gyvenviečių apylinkès. Šis parajonis iš bendro Lietuvos konteksto išsiskiria santykinai gana aukštu rinkiminiu aktyvumu (aukštesnis rinkiminis aktyvumas būdingas tik Pietryčių Lietuvos I. a. parajoniui). Tokia situacija Raseinių r. sav. susiklostè todèl, kad savivaldybejje santykinai didelis procentas gyventojų priklauso ìvairioms politinèms organizacijoms, todèl labiau mobilizuojami rinkejjai, didesnis pasitikejimas partijomis, politikais, partinis tapatumas.

II. j. parajonis apima Kèdainių r. sav. ir dali Kauno r. savivaldybès. Pasižymi netolygiu rinkiminio aktyvumo teritoriniu pasiskirstymu. Rinkiminis aktyvumas santykinai didesnis Kèdainių r. sav. priemiesčių, miestelių ir didesnių gyvenviečių rinkimų apylinkèse. Mažesnis rinkiminis aktyvumas būdingas kaimiškosioms apylinkèms.

II. k. parajonis apima Molètų r., Ukmergès r., Anykščių r., Kupiškio r. ir Biržų r. savivaldybes. Šis parajonis išsiskiria didesniu rinkiminiu aktyvumu labiau urbanizuotose teritorijose - vidutinių miestų rinkimų apylinkèse.

II. l. parajonis apima Klemės r., Radviliškio r., Panevėžio m. ir r., Pasvalio r., Pakruojo r., Joniškio r. ir Akmenès r. savivaldybes. Šis parajonis turi panašumų i̇ prieš tai aptartus, kadangi taip pat išsiskiria didesniu rinkiminiu aktyvumu labiau urbanizuotose teritorijose - vidutinių miestų rinkimu apylinkèse. Tačiau, kaip matome 4 pav., rinkiminis aktyvumas regione yra pasiskirtęs netolygiau, palyginti su dauguma prieš tai aptartų parajonių.

III žemo rinkiminio aktyvumo regionas. Šis regionas apima Vakarų Lietuvos dalį (Vakarų, Šiaurès ir Centrinę Žemaitiją), išsiskiria savo žemu rinkiminio aktyvumo vidurkiu, pirmiausia dèl žemo aktyvumo savivaldos rinkimuose. Regione išskirti keturi parajoniai:

III. a. parajonis išsiskiria mažiausiu rinkiminiu aktyvumu visos šalies mastu. Šis parajonis apima
Skuodo r. ir Mažeikių r. savivaldybes. Kaip ir visur kitur, didesniu rinkiminiu aktyvumu išsiskiria vidutinių miestų, mažų miestų, miestelių ir didesnių gyvenviečių rinkimų apylinkès. Žemiausias rinkiminis aktyvumas būdingas kaimiškosioms rinkimų apylinkèms. Tam daugiausia įtakos turi politinių (pilietinių) iggūdžių veiksniai.

III. b. parajonis apima Plungès r., Telšių r., Šiaulių m. ir r. bei dalị Rietavo savivaldybių. Didesniu rinkiminiu aktyvumu išsiskyrè vidutinio miesto ir didmiesčio bei Plungès priemiesčių rinkimų apylinkès, o žemiausiu - Telšiu r. sav. kaimiškosios teritorijos.

III. c. parajonis apima Neringos, Klaipedos m. ir r., Šilutès r. savivaldybes. Rinkiminis aktyvumas šiame parajonyje pasiskirstęs netolygiai. Neringos ir Klaipèdos r. vidutinių miestų rinkimų apylinkèse vyrauja net ir Lietuvos vidurki viršijantis rinkiminis aktyvumas. Taip pat santykinai didesniu rinkejjų aktyvumu išsiskiria Šilutès r. sav. vidutinių miestų bei miestelių ir didesnių gyvenviečių rinkimų apylinkès.

III. d. parajonis išsiskiria santykinai didesniu rinkiminiu aktyvumu, palyginti su kitais šio regiono parajoniais. Parajonis apima Palangos $\mathrm{m}$. ir Kretingos r. savivaldybes. Didesniu rinkiminiu aktyvumu išsiskiria tik Palangos $\mathrm{m}$. sav. vidutinio miesto apylinkès. Tam daugiausia turejo ittakos aktyvus balsavimas savivaldos rinkimuose, kadangi šioje savivaldybėje ittakinga Tëvynès Sąjungos - Lietuvos krikščionių demokratų partija, pasižyminti partijai lojaliu ir pilietiškai aktyviu elektoratu.

\section{IŠVADOS}

1. Pagrindinis rinkiminio aktyvumo savivaldos ir Seimo rinkimuose disbalanso teritorinis pjūvis nustatytas miesto-kaimo ašyje, nes teritorijose, apimančiose didžiuosius miestus ir jų priemiesčius, rinkejjai prioritetą teikia Seimo rinkimams. Tai sietina su vietos valdžios „nutolimu“. Miestus juosiančiose „žiedinèse“ savivaldybėse įsikūrę priemiesčių gyventojai dažniausiai savo profesine ir kita veikla susiję su gretimais didmiesčiais, priemiestinès teritorijos nèra integralios, didmiesčių ir jų priemiesčių gyventojai santykinai mažiau bendruomeniški.

2. Santykinai didesniu rinkiminiu aktyvumu savivaldos rinkimuose išsiskyrè dauguma mažųjų 
Lietuvos savivaldybių, dalies savivaldybių centrai, taip pat tos Lietuvos savivaldybès (ypač Rytų, Pietų Lietuvoje ir Žemaitijos pietinèje dalyje), kuriose jau kuris laikas yra įsitvirtinusi viena ar kita, dažniausiai „protesto“ kategorijai priskirtina, politinè jèga arba vyksta įtempta konkurencija dèl itakos savivaldybeje.

3. Rinkiminio aktyvumo Prezidento ir Seimo rinkimuose santykis turètų rodyti didesnio pasitikejjimo vieno asmens valdžia ar kolektyvine valdžios institucija santykị, pagal kurị galima spręsti apie visuomenès politinio išprusimo lygi. Tačiau $2014 \mathrm{~m}$. Prezidento ir $2016 \mathrm{~m}$. Seimo rinkimu palyginamoji analizè parodè, kad aptarta loginè priklausomybè nepasitvirtino dèl akivaizdžiai dominavusių subjektyvių veiksnių - prioritetas Seimo rinkimams buvo teikiamas tose savivaldybèse, kuriose didelè konkurencija ir aukštas rinkejju partinio tapatumo lygis.

4. 2014-2016 m. Lietuvoje vykusių rinkimų duomenimis, didžiausiu rinkiminiu aktyvumu pasižymejjo Rytų ir Pietų Lietuvos (ypač Pietryčių Lietuvos) rinkejjai. Vakarinèje Lietuvos dalyje rinkiminis aktyvumas buvo mažiausias, o Vidurio ir Šiaurès Lietuvoje užèmė pereinamą tarpinę poziciją tarp anksčiau îvardytų Lietuvos regionų.

Gauta 20181024

Priimta 20181206

\section{LITERATŪRA}

1. Anderson C., Dalton R. 2011. Citizens, Context, and Choice: How Context Shapes Citizens Electoral Choices. New York: Oxford University Press.
2. Bulhlmann M. 2006. Individual and contextual determinants of electoral participation. Swiss Political Science. 12(4): 13-47.

3. Ivanauskytė E. 2011. Rinkiminio aktyvumo dinamika 1992-2011 m. teritoriniu aspektu Lietuvoje: bakalauro darbas. Vilnius: VU Geografijos ir kraštotvarkos katedra.

4. Jasiulevičienè R. 1999. Dalyvavimas ir komunikacija. Iš: J. Matakas (sud.). Šiuolaikine valstybe. Kaunas: Technologija. 67-77.

5. Kavaliauskas P., Daugirdas V. 1993. Lietuvos politinio rajonavimo problema. Geografija. 29: 90-94.

6. Krupavičius A. 1998. Rinkèjų elgsena ir balsavimas. Iš: A. Krupavičius (sud.). Seimo rinkimai'96: trečiasis atmetimas. Vilnius: Tvermè.

7. Kvedaraitè A. 2017. Vietovés įtaka Lietuvos rinkejju aktyvumui: bakalauro darbas. Vilnius: VU TSPMI.

8. Labulytè R. 1998. „Politiniai“ regionai Lietuvoje. Iš: A. Krupavičius (sud.). Seimo rinkimai'96: trečiasis atmetimas. Vilnius: Tvermè.

9. Petrulis V. 2009. Lietuvos politinio lauko teritoriné struktūra (elektorinio metodo pagrindu): daktaro disertacija. Vilnius: VU.

10. Ramonaitè A. 2006. Kodèl rinkèjai ne(be)balsuoja? Iš: Neatrasta galia. Lietuvos pilietinès visuomenés žemélapis. Vilnius: Versus Aureus. 92-112.

11. Riekašius R. 2004. Politinis dalyvavimas. Iš: A. Krupavičius, A. Lukošaitis (sud.). Lietuvos politine sistema: sąranga ir raida. Vilnius: Poligrafija ir informatika. 213-242.

12. Tučas R. 2016. Rinkimu geografija. Vilnius: Vilniaus universitetas.

13. Žèruolis D. 1998. Racionalūs rinkèjai. Absenteizmo priežastys. Iš: A. Krupavičius (sud.). Seimo rinkimai'96: trečiasis atmetimas. Vilnius: Tvermè.

14. Žiliukaitè R. 2014. Kas Lietuvoje (ne)balsuoja? Dalyvavimo rinkimuose veiksniai. Iš: A. Ramonaitè (red.). Kaip renkasi Lietuvos rinkejjai? Idejos, interesai ir ivaizdžiai politikoje. Vilnius: Vilniaus universiteto leidykla. 65-88. 
Dovydas Vidzbelis, Rolandas Tučas

\section{TERRITORIAL DIVERSITY OF LITHUANIAN} CITIZENS ELECTION ACTIVITY FOR 2014-2016

\section{Sum mary}

This paper examines Lithuanian election activity in 2014-2016 on the basis of municipal councils, parliamentary and presidential elections. The main goal of the work is to determine the causes of the activity of Lithuania's voters from a territorial point of view. In this publication, there is presented a working methodology which was used in the study. Also, an overview of why election activity is important in Lithuania is provided. The main factors determining the activity of voters are distinguished according to foreign and Lithuanian authors' literature. The groups of internal, external and joint factors are used in this study. Internal factors include: socio-economic status, political (civil) skills, and support for political parties. External factors include: functionality of political system, geopolitical influence, and group of geographic and natural conditions. There was distinguished a group of social networks with internal and external features and other factors. Election activity in Lithuania was determined by more different factors; however, their influence was very low. Each group of factors is described in detail and justified by an example from Lithuania. The paper presents two maps depicting differences in election activity: municipal councils vs. parliamentary and parliamentary vs. presidential. Elections activity was analyzed based on special territorial units formed by grouping election districts. Six groups were formed: big cities, middle cities, suburbs, small towns, townships and larger settlements, and rural areas. The differences of election activity were discussed by different types of elections. In this paper, regions and subregions are presented according to the average activity of election. This publication reveals that the electorate of eastern and southern Lithuania (especially southeast Lithuania) was the strongest election activist. In western Lithuania election activity was the lowest, and in central and northern Lithuania it took a transitional position between the previously named regions of Lithuania.

Keywords: election, election geography, election activity, Lithuanian election regions 